\title{
REVIEW
}

\section{The Ecological Significance of the Submarine Discharge of Groundwater}

\author{
R. E. Johannes \\ CSIRO Division of Fisheries and Oceanography, P. O. Box 20, North Beach, Western Australia 6020
}

\begin{abstract}
Discharge of groundwater into the sea is widespread. Overlooking it may lead to serious misinterpretations of ecological data in studies of coastal pollution, of benthic zonation and productivity, and of the flux of dissolved substances within and between bottom sediments and overlying water. Data are presented indicating that in the Perth region of Western Australia, submarine groundwater discharge delivers several times as much nitrate to coastal waters as does river runoff.
\end{abstract}

\section{INTRODUCTION}

The literature on submarine groundwater discharge (SGD) is scattered and fragmentary. Collectively, however, it suggests that SGD deserves more attention than it has received from marine ecologists. Among those who have published recent studies relating to SGD (e. g. Kay et al., 1975; Marsh, 1977; Teal and Valiela, 1978; Valiela et al., 1978), there seems to be little awareness of other relevant work judging by the scant reference made to it. Perhaps this reflects an assumption that SGD is an unusual phenomenon. Smith (1955) for example, stated that the freshwater seepage he observed along the shore on the Isle of Cumbrae, Scotland, 'may be peculiar to this beach. But SGD occurs anywhere that an aquifer (waterbearing geological formation) is connected hydraulically with the sea through permeable bottom sediments and the head is above sea level. Such conditions are widespread (e. g. Emery and Foster, 1948; Isaacs and Bascom, 1949; Manheim, 1967; Kudelin et al., 1971; Zektzer et al., 1973).

Theoretical models of SGD from a homogeneous unconfined aquifer indicate that freshwater flows out along the coast through a narrow gap between the freshwater - seawater interface ('zone of diffusion', Fig. 1) and the water table outcrop at the beach (Hubbert, 1940; Glover, 1959). Toward the seaward edge of this zone the discharged water will be brackish because of the entrainment of some salt water from the zone of diffusion (Cooper, 1959). The width of the zone of discharge may be expected to be proportional to the volume of freshwater flow (Glover, 1959).

Harr (1962) predicted that the rate of discharge from the zone of diffusion decreases rapidly with distance from shore (see also Hubbert, 1940). This was confirmed in lakes by McBride and Pfannkuch (1975), John and Lock (1977), Lock and John (1977), and Lee et al., (1980). Only recently has the same relationship been demonstrated directly along a maríne coastline. Bokuniewiscz (1980) found that SGD decreased roughly exponentially with distance from shore in Great South Bay, New York. Between $40 \%$ and $98 \%$ of the total flow occurred within $100 \mathrm{~m}$ of shore.

An underlying salt wedge typically intrudes beneath the freshwater aquifer along marine coastlines (Fig. 1) much as it often does beneath freshwater in an estuary. This wedge impedes the downward mixing of lighter groundwater, thus magnifying the tendency for groundwater from unconfined aquifers to discharge close to shore.

Because the beach water table rises and falls in response to the tides but tends to lag behind the tides (Emery and Foster, 1948), the zone of discharge may extend above the water line at low tide. The term, submarine groundwater discharge, as used in this paper, includes all freshwater discharged below the high tide mark, including water discharged from the beach above sea level at low tide.

If, as the above observations indicate, SGD from an 
unconfined aquifer is restricted largely to the upper portion of that aquifer (Fig. 1) then the seaward movement of groundwater at the coast should be much faster (but restricted to much shallower depths) than the mean rate of coastward movement of water throughout the entire aquifer. Observations of Isaacs and Bascom (1949) on groundwater movement through 10 widely separated beaches along the west coast of the United States support this notion. Groundwater movement across the beaches observed by these authors averaged about $0.3 \mathrm{~m} \mathrm{hr}^{-1}$, whereas, in an aquifer as a whole, groundwater typically moves toward the sea at a rate of from $1.5 \mathrm{~m}$ per year to $1.5 \mathrm{~m}$ per day (Todd, 1959).

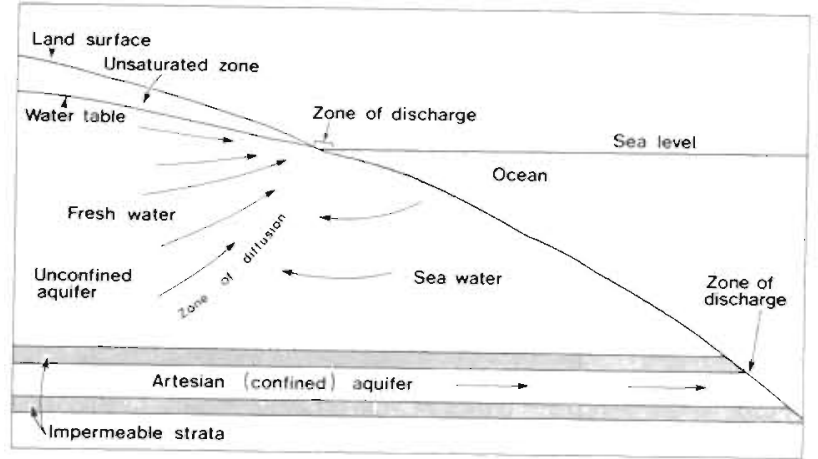

Fig. 1 Idealized representation of submarine groundwater flow

The foregoing discussion pertains to SGD from a homogeneous unconfined aquifer. Departures from ideal, i. e. homogeneous, conditions introduce complications. Kohout (1964) states, for example, that in Florida the salt water front (zone of diffusion) may be as much as 8 miles $(14 \mathrm{~km})$ seaward of the Florida coast and of the locations predicted by theory. In such areas SGD from the unconfined aquifer may presumably occur anywhere within 8 miles $(14 \mathrm{~km})$ of shore.

In contrast to unconfined aquifers, confined (artesian) aquifers may outcrop from the ocean floor at any depth or distance from shore. Artesian springs are common off many coasts (e. g Zektzer et al., 1973). Fresh or brackish artesian aquifers have been encountered while drilling as far as $120 \mathrm{~km}$ offshore (Manheim, 1967; Manheim and Sayles, 1974) The recent Atlantic Margin Coring Project revealed that 'relatively fresh groundwater occurs beneath much of the Atlantic continental shelf' (Hathaway et al., 1979, p. 52).

Of what magnitude and ecological consequence is SGD? Garrels and MacKenzie (1967) state that rivers are the major sources of dissolved and particulate materials for the oceans. They estimate that, globally, groundwater discharge into the sea amounts to about $10 \%$ of the volume discharged in surface runoff. Nace
(1970) estimated that global SGD amounts to only about $1 \%$ of surface runoff. Both estimates are based, of necessity, on sketchy data, but it seems clear that surface runoff dwarfs SGD on a global basis. Nonetheless, a number of observations indicate that SGD can be of major ecological significance.

\section{Nitrate in SGD}

Fixed nitrogen has generally been found to be the nutrient present in the lowest concentrations in coastal waters relative to the nutrient requirements of marine plants (e. g. Ryther and Dunstan, 1971; Goldman et al., 1973; Eppley et al., 1979). Nitrate levels in SGD in various parts of the world (Table 1) are two to three

Table 1 Nitrate levels in submarine groundwater discharge

\begin{tabular}{lcc|}
\hline \multicolumn{1}{c}{ Location } & $\mathrm{NO}_{3} \mu g-\mathrm{at} \mathrm{l}^{-1}$ & \multicolumn{1}{c|}{ Reference } \\
\hline $\begin{array}{l}\text { Great Sippewisset } \\
\text { Marsh, Massachusetts, } \\
\text { USA }\end{array}$ & $20-80$ & Valjela et al. (1978) \\
$\begin{array}{l}\text { Agana Bay, Guam } \\
\text { Western Island of }\end{array}$ & 178 & Marsh (1977) \\
$\begin{array}{l}\text { Hawaii, USA } \\
\text { Near Perth, Western } \\
\text { Australia } \\
\text { Discovery Bay, Jamaica }\end{array}$ & $115-380$ & This study \\
\hline
\end{tabular}

orders of magnitude greater than those of typical coastal waters. In such areas SGD is clearly a nitrate source for coastal waters. But of what importance is it relative to surface runoff?

Nitrate levels in surface runoff are extremely variable, but it is safe to say that typical values are significantly lower than those reported for SGD (Table 1) Thus it is possible that where the rate of SGD is less than that of surface runoff, it may nevertheless be more important than surface runoff in terms of nitrate transport. An area on the Swan Coastal Plain, southwest Australia, is a case in point.

Biomass and productivity of benthic algae and seagrass is high in the coastal waters bordering this coastal plain (e.g. Kirkman, pers. comm.) Yet, offshore waters in the region are low in plant nutrients (e. g. Rochford, 1962), upwelling is not known to occur (Rochford, pers. comm.), nitrogen fixation in benthic communities is low (Wiebe, unpubl.) and surface runoff is limited and restricted largely to three or four months during the rainy season. What, then, is the main source of nutrients that support high nearshore productivity? To pursue this question I decided to in- 
vestigate the quantities of nutrients delivered into coastal waters in the area via submarine groundwater discharge (SGD).

The unconfined aquifer basin to be discussed here is in the north Perth area and forms a prominent mound. called the Gnangara Mound, rising about $70 \mathrm{~m}$ above sea level. Groundwater from it flows radially towards the aquifer boundaries. It is bounded to the north by the Swan River which flows through the city of Perth; to the south by Gingin Brook and the lower Moore River which converge and discharge to the sea about $80 \mathrm{~km}$ north of the Swan River mouth; to the west by the Indian Ocean (Fig. 2). Because Perth depends upon groundwater for a significant and increasing fraction of its water supply, considerable research on groundwater dynamics has been carried out on this aquifer basin. Allen (1976) calculated conservatively that $102 \times 10^{6} \mathrm{~m}^{3}$ of groundwater discharges annually from the unconfined aquifer into coastal waters along the western edge of the basin.

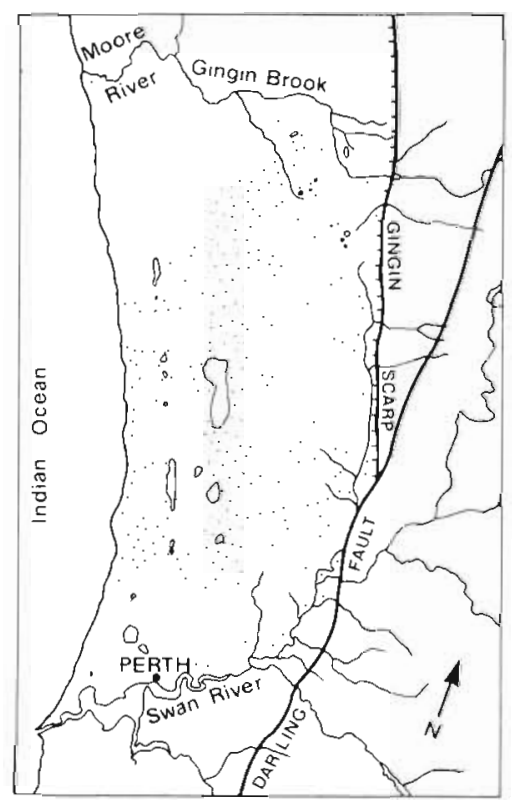

Fig. 2. Location of the unconfined aquifer in the north Perth area of Western Australia

Based on streamflow records (Public Works Dept., Western Australia, Water Resources Section, unpubl. data) and calculated groundwater discharge into the Swan River Estuary and lower Moore River system (Allen, 1976) it can be calculated that the mean annual volume of surface runoff into coastal waters is about $490 \times 10^{6} \mathrm{~m}^{3}$, or about 4.8 times the volume of groundwater discharged to the sea annually from the unconfined aquifer.

$\mathrm{SGD}$ in this area is apparently rather constant sea- sonally. Since the head driving groundwater seaward is about $70 \mathrm{~m}$ above sea level and the water table fluctuates seasonally by 0.2 to $1.5 \mathrm{~m}$ (Allen, 1976), typical summer drought conditions reduce this head by less than $2 \%$ In contrast surface runoff virtually ceases for 8-9 months.

Perth is an area of low rainfall (800-900 $\mathrm{mm} \mathrm{yr}^{-1}$ ) and sandy, highly permeable soil. All else being equal, the greater the soil permeability, the higher will be the ration of SGD to surface runoff. Similarly, the lower the rainfall the greater will be the ratio of SGD to surface Iunoff ${ }^{*}$. Perhaps it is for these reasons that the ratio of SGD to surface discharge in this area, conservatively estimated, is considerably higher than the estimated global average. (Additional SGD is thought to occur from artesian aquifers underlying the unconfined aquifer on the Swan Coastal Plain [Allen 1979], but no information on rates is available. About $20 \mathrm{~km}$ south of the study area, in Cockburn Sound, underwater drillers struck fresh water $6 \mathrm{~m}$ below the sea bottom in $20 \mathrm{~m}$ of water, creating an underwater artesian spring of sufficient force to hamper subsequent drilling [G. Wookey pers. comm.]).

The following paragraphs describe preliminary results of a study carried out to determine the significance of SGD in the area as a source of nitrate for coastal waters bordering the northern Swan Coastal Plain.

The coast in this area is bordered by sand beaches intersected by limestone outcrops. Numerous obvious sites of discharge were found in the lower intertidal zone and were usually associated with the limestone outcrops. This is propably because the solution-riddled limestone in the area is more transmissive than the surrounding sand (Allen, 1976). Here nearshore water is characterized by lower salinities than adjacent waters, and, in some cases, by clusters of small freshwater springs made visible by the plumes of sand they suspend and by birefringence due to mixing of waters of different salinites. Some of these springs are exposed at low tide, at which time seagulls can sometimes be seen drinking from them.

Nitrate levels in SGD taken at several locations along a $5 \mathrm{~km}$ strip of coastline bordering metropolitan Perth (from Trigg Island to Marmion) were all about $380 \mu \mathrm{g}$-at $\mathrm{l}^{-1}$. Nitrate levels in SGD sampled at rural sites north of Perth ranged from 115 to $215 \mu \mathrm{g}$-at $\mathbf{l}^{1}$, with a mean of $180 \mu \mathrm{g}$-at $\mathrm{l}^{1}$. (The higher levels around Perth probably reflect the heavy use of garden fertilizers and septic tanks in the area. Groundwater nitrate levels in some areas of Perth have risen significantly in the past ten years; e. g. Martin, 1980). Negative linear

- In extreme cases, i. e. coastal deserts, rainfall is so low and evaporation so high that virtually no freshwater enters the sea either as SGD of surface runoff 
correlations between nitrate and salinity in nearshore waters near sites of SGD indicate that biological uptake of nitrate was slow relative to the rate of dilution of discharged groundwater with seawater.

Several hundred experimental bores have been drilled into the coastal plain to the north of Perth. Nitrate levels in these bores range from undetectable in some areas to more than $1000 \mu \mathrm{g}$-at $\mathrm{l}^{-1}$ in some areas influenced by discharge from septic tanks or other human activities (Perth Metropolitan Water Board, unpub. data). Nitrate levels in water from most of these bores are, however, substantially lower than those found in SGD. One possible explanation for this apparent discrepancy relates to plant zonation in the area. Running along the coast is a strip about $1.5 \mathrm{~km}$ wide, the Quindalup Dune System, dominated (uniike plant communities further inland) by a number of species of the nitrogen-fixing genus Acacia (Speck, 1952). The leaching into coastal groundwater of fixed nitrogen derived from the activities of these legumes may contribute to the high nitrate levels in nearby SGD.

Using SGD nitrate data and Allen's (1976) figure for volume of SGD it can be calculated that groundwater from the unconfined aquifer supplies coastal waters between the mouths of the Swan and Moore rivers with about 370 metric tons of nitrate nitrogen $\mathrm{yr}^{-1}$. It is not possible at present to make a satisfactory estimate of the annual rates of discharge of nitrate in the area via river runoff. Nitrate levels have not been measured in the Moore River. Nitrate levels in the eutrophic Swan River estuary vary by a factor of at least ten from one year to the next at the same location during the rainy season when the river discharges to the sea (Jack, 1977). The highest nitrate concentration recorded near the mouth of this estuary is $24 \mu \mathrm{g}$-at $\mathrm{l}^{-1}$ (Jack, 1977), or about one tenth of the mean concentration found in SGD. If, for the sake of calculation, we accept this extreme value as characteristic of river runoff in general in the area, a conservative estimate can be made of the ratio of groundwater nitrate to river nitrate delivered annually to coastal waters bordering the aquifer. This ratio is about $3: 1$. It must be considered a conservative estimate for three additional reasons. First, the unknown contribution of artesian aquifers to SGD has of necessity been ignored. Second, precipitation falling beyond the boundaries of the aquifer basin contributes to the runoff from Moore and Swan watersheds. To compare surface runoff with SGD derived from precipitation within the boundaries of the aquifer basin, it would be necessary to substract this contribution from the total runoff of Moore and Swan Rivers. This has not been done since the appropriate data are not available. Third, Allen's (1976) figure for the rate of SGD from the unconfined aquifer was conservatively calculated. In short, although accurate quantification is not possible at present, it can nonetheless be stated that SGD from the aquifer basin supplies several times as much nitrate to coastal waters as does surface runoff.

Maximum levels of phosphate found in SGD were less than $2 \mu \mathrm{g}$-at $\mathrm{l}^{-1}$. Most phosphate in the groundwater of the Swan Coastal plain appears to be precipitated or absorbed in regions bearing soil high in organic matter or iron (e. g. Whelan et al., 1979; Martin, 1980). The maximum ammonia concentration found in SGD in the Perth area was less than $0.5 \mu \mathrm{g}$-at $\mathrm{l}^{-1}$. Ammonia is often rapidly oxidized to nitrate as it percolates through the soil under aerobic conditions above the water table in the Perth area (e. g. Whelan et al., 1979) although in some areas of the aquifer north of Perth ammonia levels exceed those of nitrate ( $M$. Hillman, pers. comm.).

The extent to which nitrate in SGD actually supports the nearshore marine productivity in the area cannot be estimated accurately at present, for it requires knowing rates of uptake by algae and seagrass and rates of flushing of these waters by nutrient-poor offshore waters, and this information is not available (although research is underway at this laboratory on these questions). During the months of September through December, however, nitrate values in coastal waters are generally below the level of detection except in the immediate vicinity of groundwater discharge (CSIRO Division of Fisheries \& Oceanography, Marmion, unpubl. data). This suggests that, during these months, nitrate entering these waters in SGD will be rapidly removed by algae and seagrasses.

There are only a few readily available data with which to compare the quantity of nitrate released via SGD from the Gnangara Mound. (It appears, however, as if data might be found in hydrogeological reports with limited circulation). On the west coast of the island of Hawaii, an area of high soil permeability and low rainfall, Kay et al. (1977) report that virtually all freshwater entering the sea is as SGD. Associated nitrate discharge rates averaged about $29 \mathrm{~kg} \mathrm{~m}^{-1}$ (46.7 $\mathrm{kg} \mathrm{km}^{-1}$ ) of coastline $\mathrm{d}^{-1}$, that is, about three times the mean rate calculated in this paper for the coastline north of Petth. Maksimova et al., (1978) calculated that SGD supplies about one-fifth as much fixed nitrogen to the Caspian Sea as is supplied by surface runoff. Valiela and Teal (1979) report that SGD supplies the largest fraction of the net input of fixed nitrogen in a Massachusetts salt marsh. Marsh (1977) frequently observed nitrate levels exceeding the limit of his analytical method (45 $\mu \mathrm{g}$-at $\mathrm{l}^{-1}$ ) in SGD in nearshore Guam waters.

These observations, along with others discussed below, suggest that the interpretation of much marine ecological data could be in error as a consequence of overlooking the effects of SGD. 


\section{SGD and the Benthic Boundary Layer}

Perhaps nowhere is this more likely than in studies of the exchange of substances between the sea bottom and the water column. Typically, in order to measure such fluxes, a chamber is inverted over the bottom and water samples are withdrawn periodically for chemical analysis. The chamber is generally sealed, thereby tending to reduce any SGD that might normally occur. But, since freshwater is lighter than seawater, replacement of some ot the incubation water with groundwater can still proceed, albeit at a reduced rate. Under such conditions the observed chemical changes in the chamber cannot be attributed solely, as they generally are, to metabolic activities of the benthic community and molecular diffusion. Neither can the rates of flux they represent be assumed to reflect those of the unconfined system. The absence of the word 'groundwater' from the index of the proceedings of a recent international, interdisciplinary conference on the benthic boundary layer (McCave, 1976), exemplifies the lack of attention paid to SGD by many workers.

Of the many published reports on the flux of dissolved substances across the benthic boundary layer in which the possible effects of SGD have been overlooked I will give two examples. McRoy et al., (1972) reported a net export of $62 \mathrm{mg} \mathrm{PO}_{4} \mathrm{~m}^{-2}$ from seagrass beds in Izembek Lagoon, Alaska. They speculated that chemical weathering of sediments supplied the necessary phosphorus. However they found only enough phosphorus in the seagrass rhizosphere to support the observed phosphorus export for about $110 \mathrm{~d}$. Their study site was in the intertidal region in sandy sediments - conditions favoring SGD. The possibility that SGD was a significant source of the exported phosphate thus deserves examination.

Carpenter and McCarthy (1978) suggest that the organic substrates available in Long Island Sound bottom communities were insufficient to support the rates of benthic regeneration of ammonia reported by Rowe et al., (1975). Perhaps SGD in the area (e. g. Cohen et al., 1968) supplied the excess ammonia.

Except under conditions where the existence of groundwater seepage can be ruled out, incubation vessels used to measure chemical transfers across the benthic boundary layer should incorporate in their design the capacity to allow seepage to occur at normal rates. For this purpose a chamber designed by Lock and John (1978) to measure seepage rates in lakes possesses a vent to which a collapsed condom is attached. The rate at which the condom fills can be used to calculate the rate of seepage. Lee (1977) and Lee and Cherry (1978) describe similar devices.

Small decreases in salinity in benthic incubation chambers may reflect large changes in nutrient levels in the presence of SGD. In areas of SGD near Perth a decrease in salinity of $1 \%(0.35 \%)$ corresponds to a nitrate increase of about $2-4 \mu \mathrm{g}$-at $\mathrm{l}^{-1}$ This is several times the mean nitrate concentration of undiluted sea water in the vicinity

Salinity changes during incubation should thus be measured as accurately as possible to aid in determining what fraction of observed changes in concentrations of dissolved substances may be due to SGD rather than metabolic processes, molecular diffusion etc.

\section{Interstitial Groundwater and Ecological Zonation and Productivity}

The salinity of interstitial waters of many coastal sediments is lower than that of sea water due to the presence of brackish or fresh groundwater (e. g. Kudelin, 1971). Relationships have been reported in such areas between interstitial salinity and the composition of interstitial microfauna (e. g. Bruce, 1925; Remane et al., 1934; Smith, 1955; Moore, 1979), of overlying algal mats (Sanders, 1979) and the presence of a burrowing crab (George, 1962). Kohout and Kolipinksi (1967) observed a relationship between groundwater seepage and the composition of seagrass beds and associated fauna. Relations between interstitial salinity and the distribution and growth of mangroves are reviewed by MacNae (1968). Similar relationships in rooted salt marsh plants are reviewed by Nestler (1977a) and Smart and Barko (1978).

Chapman (1976) concluded that chloride and sodium ions 'are by far the most important' chemical constituents of the soil in salt marshes. But others have pointed out recently that nutrient levels may be more important than previously suspected in governing the growth and composition of rooted aquatics in coastal areas (e. g. Lugo et al., 1974; Nestler, 1977a). Valiela and Teal (1974) state that fixed nitrogen is one of the most important limiting factors for salt marsh vegetation.

Since groundwater may contain high concentrations of nitrate relative to those of seawater, (e. g. Table 1) a negative correlation between nitrate levels and salinity (as found in the present study) might be expected where the two types of water mix. Thus the functional significance of correlations between interstitial salinity and the distribution of organisms in rooted aquatic communities may not be as simple as has sometimes been supposed. For example, more vigorous growth of some rooted aquatics at reduced interstitial salinities (e. g. MacNae 1968) might be as much a consequence of elevated nutrient availability in some instances as it is of reduced osmotic stress. 
Deducing the presence of groundwater under emergent rooted aquatic communities, i. e. mangroves and salt marshes, may not be straightforward however. Salinities in the rhizosphere may be greater than in overlying surface waters (e. g. Penfound and Hathaway, 1938) due to evaporation at low tides (e. g. Nestler, 1977b) and to translocation and transpiration of water by the plants. Nutrient levels may also be reduced due to plant uptake.

Revelle (1941) recommended the chloride-bicarbonate ratio as a means of diagnosing the intrusion of seawater into saline groundwater. The same ratio might be used as a means of diagnosing the mixing of groundwater with seawater in hypersaline interstitial water beneath emergent rooted aquatic communities. Chloride often occurs only in small amounts in groundwater. Bicarbonate is usually the most abundant negative ion in groundwater while occurring in relatively minor amounts in seawater. High ammonia levels and sulphate reduction activity, both often found in sediments in the vicinity of rooted intertidal aquatics, could, however, lead to elevated pH's (e. g. LIMER expedition team 1976) with an accompanying change in bicarbonate levels, thereby complicating the interpretation of chloride-bicarbonate ratios.

Lugo et al., (1974) point out that the largest and most vigorous mangrove stands are always associated with riverine conditions', and suggest that this is due to the delivery of large quantities of nutrients in runoff. Those portions of mangrove roots which absorb nutrients are not in the surface water, however, but in the sediments below. And the water table along the edges of rivers is generally close to the surface. Thus the availability of nutrients in groundwater may be more important in mangrove ecology than nutrients in surface runoff. It might be suggested that nutrients delivered in rivers' suspended loads and subsequently worked into the mangrove rhizosphere account for the observed high biomass in these areas. Undoubtedly some nutrients enter the rhizosphere in this manner. But Lugo et al., (1975) state that most vigorous mangrove stands are always associated with 'conditions where detritus accumulation is low'

Radioisotopic experiments in Georgia salt marshes indicate that the roots of a nother rooted coastal aquatic can be relatively isolated from overlying waters. When Pomeroy et al. (1967) labelled estuarine waters with $\mathrm{P}^{32}$ and $\mathrm{Zn}^{65}$ very little was taken up by cordgrass Spartina alterniflora. When $\mathrm{P}^{32}$ was introduced into the sediments, however, it was readily taken up (Reimold 1972) Studies of the movement of dye in salt marsh sediments also indicated little exchange of water between sediments and overlying water (Nestler, $1977 \mathrm{a}$, b).

\section{Sculpturing of Calcareous Shorelines by Discharging Groundwater}

Calcareous shores sheltered from heavy wave attack often display marked indentations or undercuts along the waterline, particularly in tropical and subtropical areas. The origins of these features has long been disputed. The controversy has centered in recent years on whether they are caused mainly by solution by seawater or by erosional effects of marine animals Higgins (1980) reviews this controversy, and casts doubts on either hypothesis as a satisfactory general explanation.

Higgins (1980) resurrects the hypothesis of Wentworth (1939) who proposed that intertidal limestone undercuts are formed by groundwater. Higgins (1980, p. 23) states that observers after Wentworth, 'seem to have been unaware of the pool of freshwater hidden beneath the land surface and of its steady discharge through porous rock at the shore. Consequently they have tended to consider only the visible features waves, surface runoff, seawater and marine organisms - as potential agents of coastal erosion. Yet, wherever the groundwater is undersaturated with respect to calcium carbonate, it is capable of dissolving limestone, and at such places may be far more effective than all these other agents in the formation of coastal nips and notches'

In support of this hypothesis, Higgins (1980) describes how, along the coast of Greece, calcareous shorelines deeply undercut at the water line are limited to areas where coastal springs flow into the sea. As little as $100 \mathrm{~m}$ away from such sites identical rocks are not undercut. Higgins (1980, p. 19) notes that, whereas limestone is not very soluble in fresh rainwater, 'Karst regions show that rainwater is a very effective solvent of limestone when it is charged with $\mathrm{CO}_{2}$ derived from organic matter on and in the soil'.

\section{SGD and the Distribution of Island Marine Flora}

Alyae of the genus Sargassum are common around high tropical islands but seldom found around low islands (Doty, 1954; Tsuda, 1976). A similar distribution is characteristic of the seagrass Enhalus acoroides (Tsuda et al., 1977). Groundwater seepage is highly variable temporally around low islands and closely coupled to rainfall (e. g. Wentworth, 1947; Guinther, 1974). In areas where rainfall is strongly seasonal, rates of SGD from large islands are likely to be more stable seasonally than SGD from small ones. This is because groundwater storage capacity increases as the square of island linear dimension - i. e. as a function of island area - whereas the rate of SGD is proportional to the 
island perimeter and hence to the first power of island linear dimensions (Wentworth, 1947). This relationship also implies that, all else being equal, the larger the island the greater the mean rate of SGD km-1 of coastline. Thus, given the same rainfall, the rate of SGD $\mathrm{km}^{-1}$ of coastline from an island $20 \mathrm{~km}$ in diameter would be 10 times that from an island $2 \mathrm{~km}$ in diameter. Does the greater rate of SGD per unit of coastline and greater seasonal uniformity of SGD around high islands confer upon their coastal marine habitats characteristics essential to the survival of some species? It is perhaps not coincidental that Enhalus acoroides is the last species of seagrass to drop out with decreasing salinities in estuarine conditions (Kock and Tsuda, 1978; Johnstone 1979) and has been observed growing at sites of groundwater discharge (Marsh, 1977).

\section{Ecological Impacts of the Modification of Coastal Groundwater}

Although an extensive literature exists on the landbased problems associated with depletion or pollution of groundwater, little thought has been given to the influence of such alterations on coastal marine communities. Greatly increased pumping of groundwater from the Swan Coastal Plain for domestic use is anticipated in the next few years, with a consequent reduction in SGD. What effects will this have on adjacent marine communities? Commercial fish and lobster yields have been found to be positively correlated with the rate of discharge into coastal waters of land-based nutrients (e. g. Sutcliffe, 1972). And what are the effects on coastal communities of the submarine discharge of polluted water? The impacts on rooted aquatics in areas of polluted interstitial groundwater might be very different from those of similarly polluted surface runoff.

Because groundwater often moves seaward through the soil at rates of only 1 to a few $\mathrm{m} \mathrm{yr}^{-1}$ (e. g. Todd, 1959) pollution of coastal waters due to contaminated SGD may commence only many years after inland pollution began. If remedial measures are not taken until after such coastal pollution is already in evidence, abatement might take decades. In environmental studies of coastal waters influenced by man more emphasis should therefore be put into monitoring the landward aquifers to which they are hydraulically connected. In some cases the desired data may be readily obtainable from hydrogeologists.

\section{CONCLUSION}

The impact on marine and estuarine communities of the discharge of submarine groundwater is less, on a global scale, than that of surface runoff. It is nevertheless clear that SGD is widespread and, in some areas. of greater ecological significance than surface runoff. SGD influences productivity, biomass, species composition and zonation. Alterations in coastal groundwater quantity or quality by man may bring about changes in marine communities by means of altered salinities, dissolved nutrient concentrations or levels of dissolved pollutants. In marine ecological studies more emphasis seems desirable on examining the influences of SGD and into monitoring its landward sources.

\section{LITERATURE CITED}

Allen, A. D. (1976). Outline of the hydrogeology of the superficial formations of the Swan Coastal Plain. Western Australia Geol. Surv. Ann. Rep. 1975: 31-42

Allen, A. D. (1979). An outline of the confined groundwater resources in the vicinity of Perth, Western Australia. Western Australia Geol. Surv. Ann. Rep. 1978: 77-84

Bokuniewiscz, H. (1980). Groundwater seepage into Great South Bay, New York. Estuar \& coast. mar. Sci. 10: $437-444$

Bruce, J. R. (1925). The metabolism of shore-living dinoflagellates. Br. J. exp. Biol. 2: 413-426

Carpenter, E. J., McCarthy, J. J. (1978). Benthic nutrient regeneration and high rate of primary production in continental shelf waters. Nature, Lond. 274: 188-189

Chapman, V. J. (1976). Coastal vegetation, 2nd ed., Pergamon Press, Oxford

Cohen, P., Franke, O. L., Foxworthy, B. L. (1968). An atlas of Long Island's water resources. N. Y Water Resources Commission Bull. 62

Cooper, H. H., Jr. (1959). A hypothesis concerning the dynamic balance of fresh water and salt water in a coastal aquifer. J. geophys. Res. 64: 461-467

Doty, M. S. (1954). Distribution of the algal genera Rhipilia and Sargassum in the central Pacific. Pacif. Sci. 8: 367-368

Emery, K. O., Foster, J. F. (1948). Water tables in marine beaches. J. mar Res. 7: 644-654

Eppley, R. W., Renger, E. H., Harrison, W. G. (1979). Nitrate and phytoplankton production in Southern California coastal waters. Limnol. Oceanogr 24: 483-494

Garrels, R. M., Mackenzie, F. T (1967). Evolution of sedimentary rocks, Norton \& Co., New York

George, R. W. (1962). The burrowing shore crab of southern Australia. Aust. Nat. Hist. 14: 71-74

Glover, R. E. (1959). The pattern of freshwater flow in a coastal aquifer. J. geophys. Res. 64 (4): 457-459

Goldman, J, C., Tenore, K. R., Stanley, H. I. (1973). Inorganic nitrogen removal from waste water: effect on phytoplankton growth in coastal marine waters. Science, N. Y 180: 955-956

Guinther, E. B. (1974). Groundwater and nearshore hyposaline conditions at Fanning Island during a period of higher than normal rainfall. Pacif. Sci. 28: 319-337

Harr, M. E. (1962). Groundwater and seepage, McGraw-Hill, New York

Hathaway, J. C., Poag, C. W., Valentine, P. C., Miller, R. E., Schultz, D. M., Manheim, F. T., Kohout, F. A., Bothner, M. H., Sangrey, D. A. (1979). U.S. geological survey core drilling on the Atlantic Shelf. Science, N. Y 206 (4418): $515-527$ 
Higgins, C. G. (1980). Nips, notches, and the solution of coastal limestone: an overview of the problem with examples from Greece. Estuar \& coastal mar Sci. 10: $15-30$

Hubbert, M. K. (1940). The theory of groundwater motion. J. Geol. 48: $785-944$

Isaacs, J. D., Bascom, W N. (1949). Water-table elevations in some Pacific coast beaches. Trans. Am. geophys. Un. 30 293-294

Jack, P. N. (1977). Seasonal variations in the water of the Swan River. Govt. Chem. Laboratories Western Australia. Report of Investigations 14: 1-32

John, P. H., Lock, M. A. (1977). The spacial distribution of groundwater discharge into the littoral zone of a New Zealand lake. J. Hydrol. 33: 391-395

Johnstone, I. M. (1979). Papua New Guinea seagrasses and aspects of the biology and growth of Enhalus acoroides (I f.) Royle. Aquat. Bot. 7: 197-208

Kay, A. E., Lau, L. S., Stroup, E. D., Dollar, S. J., Fellows D. P. Young, R. H. F. (1977). Hydrological and ecological inventories of the coastal waters of West Hawaii. Univ. o Hawaii, Water Resources Research Center Technical Report 105, 94 pp

Kock, R. L., Tsuda R. T. (1978). Seagrass assemblages of Yap Micronesia. Aquat. Bot. 5: 245-249

Kohout, F. A. (1964). The flow of fresh water and salt water in the Biscayne Bay aquifer of the Miami area, Florida. Seawater in coastal aquifers. U.S. Geol. Surv. Water Supply Pap. 1616-C: 12-32

Kohout, F. A., Kolipinski, M. C. (1967). Biological zonation related to groundwater discharge along the shore of Biscayne Bay, Miami, Florida. In: Lauff, G. (ed.) Estuaries A. A. A. S. Publ. No. 83, Washington, D.C., pp. $488-499$

Kudelin, B. I., Zektzer, I. S., Meskheteli, A. V., Brusilovsky, S A. (1971). The problem of underground outflow to the sea. (Russ.) Sov. Geol. 1: 72-80

Lee, D. R. (1977). A device for measuring seepage flux in lakes and estuaries. Limnol. Oceanogr. 22: 140-147

Lee, D. R., Cherry, J. A. (1978). A field exercise on groundwater flow using seepage meters and mini-piezometers. J. Geol. Educ. 27: 6-10

Lee, D. R., Cherry, J. A., Pickens, J. F. (1980). Groundwater transport of a salt tracer through a sandy lake bed. Limnol. Oceanogr. 25: 45-61

LIMER 1975 Expedition Team (1976). Metabolic processes of coral reef communities at Lizard Island, Queensland Search 7: $463-468$

Lock, M. A., John, P. H. (1978). The measurement of groundwater discharge into a lake by a direct method. Int. Revue ges. Hydrobiol. 63: 271-275

Lugo, A. E., Sell, S. M., Snedaker, S. C. (1974). Mangrove ecosystem analysis. In: Patten. B. C. (ed.) Systems analysis and simulation ecology, Vol. 4. Academic Press, New York, pp. 114-144

McBride, M. S., Pfannkuch, H. O. (1975). The distribution of seepage within lakebeds. U.S. Geol. Surv. J. Res. 3: 505-513

McCave, I. N. (ed.) (1976). The benthic boundary layer, Plenum, New York

MacNae, W. (1968). A general account of the fauna and flora of mangrove swamps and forests in the Indo-West Pacific region. Adv. mar. Biol. 6: 73-270

McRoy, C. P., Barsdate, R. J., Nebert, N. (1972). Phosphorus cycling in an eelgrass (Zostera marina L.) ecosystem. Limnol. Oceanogr 17: 58-67

Maksimova, M. P., Katunin, D. N., Yeletsky, B. D. (1978). Balance of biogenous elements in the Caspian Sea during the period of regulated streamflow. Oceanology 18 295-297

Marbeim, F. T (1967). Evidence for submarine discharge of water on the Atlantic continental slope of the southern United States, and suggestions for further research. Trans. N. Y Acad. Sci. (Ser II) 29: 839-853

Manheim, F. T., Sayles, F. L. (1974). Composition and origin of interstitial waters of marine sediments, based on deep sea drill cores. In: E. D. Goldberg (ed.) The sea, Vol. 5. John Wiley and Sons, New York, pp. 527-568

Marsh, J. A., Jr. (1977). Terrestrial inputs of nitrogen and phosphorus on fringing reefs of Guam: In: Proceedings of the 2nd International Coral Reef Symposium, Vol. I. Great Barrier Reef Committee, Brisbane, Australia, pp. 332-336

Martin, R. (1980). Hydrogeochemical study of an unconfined aquifer in the vicinity of Perth. Western Australia. Ph. D. thesis, University Western Australia

Moore, C. G. (1979). The zonation of psammolittoral harpacticoid copepods around the Isle of Man. J. mar. biol. Ass. U. K. 59: 711-724

Nace, R. L. (1970). World hydrology; status and prospects. In World Water Balance, I. Symp. Association internationale d'hydrologie scientifique (A. I. H. S.) - UNESCO- W. H. O. Reading, August 1970. A. I. H. S. Louvain, Publ. 92 : $1-10$

Nestler, J. (1977). Interstitial salinity as a cause of ecophenic variation in Spartina alterniflora. Estuar \& coast mar. Sci. 5: $707-714$

Nestler, J. $(1977 \mathrm{~b})$. A preliminary study of the sediment hydrology of a Georgia salt marsh using Rhodamine WT as a tracer. Southeastern Geol. 18: 265-271

Penfound, W T., Hathaway, E. S. (1938). Plant communities in the marshlands of southeastern Louisiana. Ecol. Monogr. 8: $1-56$

Pomeroy, L. R., Johannes, R. E., Odum, E. P., Roffman, B. (1967). The phosphorus and zinc cycles and productivity of a salt marsh. In: Nelson, D., Evans, F.C. (eds) Proceedings 2nd Radioecology Symposium. Clearinghouse for Federal Scientific Information, National Bureau of Standards, U.S. Dept. of Commerce, Springfield, Va., pp. 412-420

Reimold, R. J. (1972). The movement of phosphorus through the salt marsh cord grass, Spartina alterniflora. Limnol. Oceanogr 17: 606-611

Remane, A. et al. (1934). Die Tierwelt des Küstengrundwassers bei Schilksee (Kieler Bucht) I-VII. Naturwiss. Verein. Schleswig-Holstein 20: 399-479

Revelle, R. (1941). Criteria for recognition of seawater in groundwaters. Trans. Am. geophys. Un. 22: 593-597

Rochford, D. J. (1962). Hydrology of the Indian ocean. II. The surface waters of the South-east Indian Ocean and Arafura Sea in the spring and summer. Aust. J mar. Freshwat. Res. 13: $226-251$

Rowe, G. T., Clifford, C. H., Smith, K. L., Jr., Hamilton, P. L. (1975). Benthic nutrient regeneration and its coupling to primary productivity in coastal waters. Nature, Lond. 255: $215-217$

Ryther, J. H., Dunstan, W M. (1971). Nitrogen, phosphorus and eutrophication in the coastal marine environment. Science, N. Y. 171: 1008-1113

Sanders, J. G. (1979). The importance of salinity in determining the morphology and composition of algal mats. Botanica mar. 22: 159-162

Smart, R. M., Barko, J. W (1978). Influence of sediment salinity and nutrients on the physiological ecology of selected salt marsh plants. Estuar \& coast. mar. Sci. 7 : $487-495$

Smith, R. I. (1955). Salinity variation in interstitial water of 
sand at Kames Bay, Millport, with reference to the distribution of Nereis diversicolor. J. mar biol. Ass. U. K. 34: $33-46$

Speck, N. H. (1952). The ecology of the metropolitan area of the Swan coastal plain. M. Sc. thesis, Unuversity Western Australia

Sutcliffe, $W$ H., Jr (1972). Some relations of land drainage, nutrients and particulate material, and fish catches in two eastern Canadian bays. J. Fish. Res. Bd Can. 29: 357-362

Teal, J. M., Valiela, I. (1978). Nitrogen budget of a coastal marine ecosystem. Rapp. P.-v. Réun. Cons. int. Explor Mer 173: 101-105

Todd, D. K. (1959). Groundwater hydrology, Wiley and Sons, New York

Tsuda, R. T (1976). Occurrence of the genus Sargassum (Phaeophyta) on two Pacific atolls. Micronesica 12: 279-282

Tsuda, R. T., Fosberg, F. R., Sachet, M.-H. (1977). Distribution of seagrasses in Micronesia. Micronesica 13: 191-198

Valiela, I., Teal, J. M. (1974). Nutrient limitation in salt marsh vegetation. In: Reimold, R. J., Queen, W. H. (eds) Ecology of halophytes. Academic Press, New York, pp. 547-563

Valiela, I., Teal, J. M. (1979). The nitrogen budget of a salt marsh ecosystem. Nature, Lond. 280: 652-656

Valiela, 1., Teal, J. M., Volkmann, S., Shafer, D., Carpenter, E. J. (1978). Nutrient and particulate fluxes in a salt marsh ecosystem: Tidal exchanges and inputs by precipitation and groundwater Limnol. Oceanogr 23: 798-812

Wentworth, C. K. (1939). Marine bench-forming processes: II, solution benching. J. Geomorphol. 2: 2-35

Wentworth, C. K. (1947). Factors in the behavior of groundwater in the Ghyben-Herzberg system. Pacif. Sci. 1: 172-184

Whelan, B. R., Barrow, N. J., Carbon, B. A. (1979). Movement of phosphate and nitrogen from septic tank effluent in sandy soils near Perth, Western Australia. Australian Water Resources Council, Preprint Papers, Groundwater Pollution Conference, Perth, pp. 226-233

Zektzer, I. S., Ivanov, V. A., Meskheteli, A. V. (1973). The problem of direct groundwater discharge to the seas. J. Hydrol. 20: 1-36 